\title{
Struktur dan Fungsi Sosial Nyanyian Rakyat Lullaby "Manjujai Anak"
}

\author{
Lilia Zahra Asifa ${ }^{1, *}$ \\ Universitas Negeri Padang \\ *Corresponding author: email: liazahra0505@gmail.com
}

Submitted: 21 April 2021

Revised: 3 July 2021

Accepted: 7 July 2021

\begin{abstract}
This research was conducted with the aim of describing the structure and social function of the folk song lullaby Manjujai Anak in the Kampuang Tabek Jorong Koto Tingga Nagari Sirukam community. This research is a qualitative research with descriptive methods which was carried out in two stages, namely the data collection stage (interview, record, transcribe, and transliterate the folk song Manjujai Anak from the original language to Indonesian), and the data analysis stage. The data were analyzed using the theory of the study of poetry structure and social functions as used by Waluyo (1987), Hasanuddin WS (2002), and Danandjaja (1991). Based on research findings the text structure of the Manjujai Anak song is more precisely formulated into a bound poetry format, which is tied to lines and stanzas. Meanwhile, the social functions found in the text of the song Manjujai Anak are as a projection system, children's educational tools, recreational functions, as well as an inheritance of an oral tradition. The results of this study can reflect the philosophy of life, perceptions, and social behavior of the Kampuang Tabek community, so this research is important to do.
\end{abstract}

Keywords. Structure, social function, folksong (lullaby), manjujai anak, nagari Sirukam.

Abstrak. Penelitian ini dilakukan dengan tujuan untuk mendeskripsikan struktur dan fungsi sosial lagu pengantar tidur lagu daerah berjudul Manjujai Anak pada masyarakat Kampuang Tabek Jorong Koto Tinga Nagari Sirukam. Penelitian ini merupakan penelitian kualitatif dengan metode deskriptif yang dilakukan dalam dua tahap, yaitu tahap pengumpulan data (wawancara, rekam, transkrip, dan transliterasi lagu daerah Manjujai Anak dari bahasa asli ke bahasa Indonesia), dan tahap analisis data. Data dianalisis dengan menggunakan kajian struktur internal puisi dan fungsi sosial seperti yang digunakan oleh Waluyo (1987), Hasanuddin WS (2002), dan Danandjaja (1991). Berdasarkan temuan penelitian, struktur teks lagu Manjujai Anak lebih tepat dirumuskan ke dalam format puisi terikat, yaitu terikat pada baris dan bait. Sedangkan fungsi sosial yang terdapat dalam teks lagu Manjujai Anak adalah sebagai sistem proyeksi, alat pendidikan anak, fungsi rekreatif, serta pewarisan tradisi lisan. Hasil penelitian ini dapat mencerminkan falsafah hidup, persepsi, dan perilaku sosial masyarakat Kampuang Tabek, sehingga penelitian ini penting untuk dilakukan.

Keywords. Struktur, fungsi sosial, lagu pengantar tidur, menjujai anak, nagari Sirukam

\section{Pendahuluan}

Meskipun masyarakat berubah namun tradisi masih tetap ada. Tradisi lokal contohnya, tradisi ini adalah kebudayaan lokal yang hidup di tengah-tengah masyarakat seperti tradisi lisan. Daerah di Indonesia yang terkenal dengan kebudayaan lisannya adalah Sumatera Barat dengan suku Minang. Dalam hal tradisi lisan, masyarakat Minangkabau memiliki tradisi menyenandungkan lagu sebagai pengantar tidur anak (lullaby). Nyanyian rakyat lullaby ini pada 
umumnya menggunakan buaian atau ayunan yang biasanya terbuat dari rotan atau hanya dengan kain panjang. Sebagai salah satu bentuk kesenian tradisional nyanyian rakyat sering kali tidak diketahui penciptanya, karena pada saat nyanyian tersebut diciptakan rasa kebersamaan masih jauh dianggap lebih penting daripada kepentingan individual. Nyanyian rakyat lullaby ini tergolong nyanyian rakyat yang berfungsi, hal ini disebabkan baik lirik maupun lagunya memegang peranan yang sama penting dan cocok dengan irama aktivitas khusus dalam kehidupan manusia (Danandjaja, 1991, p.146).

Kajian terhadap lagu pengantar tidur (lullaby) telah dilakukan oleh sebagian peneliti Minangkabau yang lebih difokuskan pada satu kajian ilmiah saja, misalnya linguistik dalam kajian semantik atau fokus pada lagu pengantar tidur (lullaby) Minangkabau (Hasanuddin, dkk., 2020, p.147-148). Sejalan dengan ini tradisi lisan dapat dikatakan sebagai aset budaya yang belum mendapatkan banyak perhatian khusus dari peneliti Minangkabau dan hal ini membuktikan bahwa tradisi lisan layak untuk dikaji serta dilestarikan. Disebabkan bentuknya yang murni lisan, tradisi ini tentu lebih rentan cepat punah karena tidak ada dokumentasinya. Oleh karena itu, upaya untuk mendokumentasikan tradisi lisan ini sangat perlu dilakukan.

Masyarakat Kampuang Tabek, Jorong Koto Tingga, Nagari Sirukam, Kecamatan Payung Sekaki, Kabupaten Solok adalah masyarakat Minangkabau yang mengenal nyanyian rakyat lullaby ini dengan sebutan Manjujai Anak. Ketika Manjujai Anak, si anak digendong memakai kain panjang, atau memasukkannya ke dalam ayunan. Kemudian, orang tua mulai manjujai dengan menepuk-nepuk bokongnya secara pelan-pelan. Selain itu, hentakan kaki orang tua akan turut mengikuti irama lagu yang dinyanyikan. Nyanyian yang disenandungkan diiringi irama yang bervariasi, sehingga menimbulkan rasa kantuk bagi si anak. Nyanyian ini biasanya berisi pesan-pesan, nasihat, petuah-petuah, cita-cita, ataupun harapan orang tua dari kecil hingga anaknya beranjak dewasa. Melalui nyanyian rakyat lullaby "Manjujai Anak" masyarakat bebas mengeskpresikan perasaannya.

Selain itu Manjujai Anak ketika tidur akan mempererat hubungan batin antara orang tua dengan anaknya. Hal ini diperkuat oleh Hutt (dalam Desmita 2006, p.101) yang mengungkapkan bahwa respon selektif bayi yang baru lahir terhadap ucapan manusia memiliki arti penting bagi kelangsungan hidupnya, sebab ia menjadi bagian vital dalam perkembangan hubungan kasih sayang antara orang tua dan anak. Oleh karena itu, tradisi lisan "Manjujai Anak" ini perlu dipertahankan keberadaannya di tengah-tengah masyarakat yang telah mengalami modrenisasi.

Berdasarkan pengamatan penulis Manjujai Anak merupakan suatu kebiasaan menidurkan anak yang sekarang masih dilakukan masyarakat Kampuang Tabek Jorong Koto Tingga Nagari Sirukam Kecamatan Payung Sekaki Kabupaten Solok. Namun, kebiasaan ini tersisih dari generasi muda. Hal ini disebabkan generasi muda mulai beralih kepada hal-hal yang berbaur modern dengan beragam alternatif dan dapat diakses dengan cara yang lebih mudah. Salah satunya dengan mendengarkan lagu-lagu non klasik yang dirasa lebih bermanfaat dan sesuai dengan perkembangan zaman. Selain itu, banyak remaja yang tidak mengerti tentang folklor lisan Manjujai Anak ini. Hal tersebut disebabkan sudah sedikit ditemukan orang yang Manjujai Anak sebagai pengantar tidur anaknya serta berkurangnya kreativitas masyarakat dalam membuat pantun.

Kurangnya minat masyarakat Kampuang Tabek pada nyanyian rakyat Manjujai Anak juga didasari orang tua dari si anak yang kebanyakan memiliki profesi seperti guru, pegawai kantoran, dan lain-lain. Tuntutan kerja memaksa orang tua untuk meninggalkan anak kepada neneknya, sehingga yang menyanyikan nyanyian rakyat lullaby ini adalah sang nenek, sedangkan orang tua dari si anak kurang mengerti atau memahami dari folklor lisan tersebut. Kemudian, kurangnya rasa percaya diri dari orang tua si anak jika harus menggunakan nyanyian dalam bahasa daerah (tradisional) juga menjadi faktor turunnya minat terhadap folklor lisan ini. Anggapan masyarakat sekarang hal-hal tersebut terkesan kuno dan ketinggalan zaman. Hal ini diperkuat oleh Hasanuddin, dkk (2020, p.638) yang mengungkapkan dalam penelitiannya 
bahwa tradisi lisan tergerus dari generasi muda karena menyanyi menggunakan bahasa tradisional terkesan kuno dan ketinggalan zaman.

Jika hal itu dibiarkan nyanyian rakyat lullaby Manjujai Anak akan punah. Oleh sebab itu, penelitian ini penting dilakukan guna mendokumentasikan nyanyian rakyat lullaby Manjujai Anak di Kampuang Tabek Jorong Koto Tingga Nagari Sirukam Kecamatan Payung Sekaki Kabupaten Solok. Sampai saat ini belum ditemukan penelitian tentang nyanyian rakyat lullaby Manjujai Anak dalam bentuk tertulis. Demikian, nyanyian rakyat lullaby Manjujai Anak belum terdokumentasi secara lengkap dan sudah menjadi kewajiban masyarakat pemilik tradisi lisan untuk menjaga keutuhan tradisi ini sebagai bentuk cinta terhadap tanah air. Adapun Kajian tradisi lisan seperti nyanyian lullaby Minangkabau selama ini hanya dilakukan sebagian oleh peneliti Minangkabau seperti Salahuddin (2014) yang melakukan penelitian tentang lagu pengantar tidur Maoundu Pojo di Kabupaten Lima Puluh Kota, Fitriana (2019) yang melakukan penelitian tentang lagu pengantar tidur Nandong di Kecamatan Kuantan Singingi, dan Marantes, dkk. (p.20-18) yang melakukan penelitian tentang studi semantik terhadap beberapa teks tradisi lisan lagu-lagu pengantar tidur kolektif masyarakat Minangkabau dari beberapa lokasi acak, sedangkan kajian terkait tradisi lisan ini belum ditemukan dari peneliti asing.

\section{Metode}

Jenis penelitian ini adalah penelitan kualitatif. Menurut McMiland dan Schumacher (2010) penelitian kualitatif adalah suatu pendekatan yang juga disebut pendekatan investigasi karena biasanya mengumpulkan data dengan cara bertatap muka langsung dan berinteraksi dengan orang-orang di tempat penelitian. Lebih lanjut, metode penelitian yang digunakan dalam penelitian ini adalah deskriptif analisis. Menurut Ratna (2011, p.53) metode deskriptif analisis dilakukan dengan cara mendeskripsikan kata-kata yang kemudian disusul dengan analisis.

Berdasarkan pendapat tersebut dapat disimpulkan bahwa penelitian kualitatif dengan metode deskriptif ini digunakan untuk menggambarkan fenomena yang ada, baik secara alamiah atau rekaan yang dialami oleh subjek penelitian dengan cara mendeskripsikan dalam bentuk kata dan bahasa. Pendeskripsian data dilakukan dengan cara menunjukkan fakta-fakta yang berhubungan dengan struktur nyanyian rakyat dengan teori kajian struktur puisi oleh Waluyo (1987), yaitu penganalisisan struktur fisik dan batin.

Struktur fisik yang dimaksud adalah perwajahan puisi yang terdiri dari baris dan bait, diksi, pengimajian, kata konkret, bahasa figuratif, dan verifikasi. Namun, pengimajian dirasa kurang tepat digunakan dalam penganalisisan. Hal ini disebabkan dalam teori Waluyo (1987) pengimajian terdiri atas tiga yaitu imaji visual, auditif, dan takjil. Sementara itu, dalam nyanyian rakyat Manjujai Anak terdapat imaji gerak yang tidak terdapat dalam teori Waluyo. Oleh karena itu, pada bagian ini penulis menggunakan teori dari Hasanuddin (2002) tentang imaji yang dikenal dengan citraan.

Kemudian dalam hal pendeskripsian fungsi sosial nyanyian rakyat dianalisis berdasarkan teori fungsi folklor oleh Danandjaja (1991) yang terdapat dalam nyanyian rakyat lullaby "Manjujai Anak" masyarakat Kampuang Tabek Jorong Koto Tingga Nagari Sirukam Kecamatan Payung Sekaki Kabupaten Solok. Adapun fungsi sosial tersebut adalah sebagai sistem proyeksi, sebagai alat pendidikan anak, rekreatif, dan nyanyian ini juga berfungsi sebagai pewarisan tradisi lisan.

\section{Hasil dan Pembahasan}

Berdasarkan klasifikasi dan analisis data ditemukan hasil yang akan dibahas dalam pembahasan melalui struktur teks dan fungsi sosial teks nyanyian rakyat lullaby "Manjujai Anak" sebagai berikut. 
1. Struktur Teks Nyanyian Rakyat Manjujai Anak Masyarakat Kampuang Tabek Jorong Koto Tingga Nagari Sirukam Kecamatan Payung Sekaki Kabupaten Solok

Pengkajian struktur dalam nyanyian rakyat lullaby "Manjujai Anak" difokuskan pada struktur fisik dan struktur batin berdasarkan teori yang telah dijabarkan sebelumnya. Adapun struktur fisik dan batin tersebut adalah sebagai berikut.

\section{Struktur Fisik}

a. Baris

Keseluruhan teks nyanyian rakyat lullaby "Manjujai Anak" memiliki lima puluh dua baris dengan tiga dan empat baris dalam satu baitnya. Data baris yang penulis temukan beragam. Hal ini dapat dilihat melalui teks nyanyian rakyat lullaby "Manjujai Anak" berikut.

(D1) Oi nak kanduang laloklah lalok

Laloklah lalok piciangkan mato

Piciangkan mato

'Oi nak kandung tidurlah tidur

Tidurlah tidur pejamkan mata

Pejamkan mata'

Berdasarkan contoh nyanyian rakyat lullaby "Manjujai Anak" di atas terlihat bahwa dalam satu baris jumlah kata yang digunakan pelantun beragam. Pada data (D1) di atas, baris pertama dalam lirik nyanyian rakyat lullaby "Manjujai Anak" di atas terdapat lima kata dalam satu baris, baris ke dua terdapat empat kata, selanjutnya pada baris ke tiga terdapat dua kata dalam satu baris. Pada keseluruhan data yang telah diidentifikasi dan diklasifikasikan paling banyak ditemukan empat kata dalam satu baris. Hal ini menunjukkan bahwa data teks nyanyian rakyat lullaby Manjujai Anak ini tergolong sebagai puisi konvensional seperti teori yang dikemukakan oleh Siswanto (2013:102) yang masih terikat dengan jumlah kata dalam satu baris. Hal ini juga sejalan dengan pendapat Atmazaki (2008:10-11) yang mengungkapkan bahwa sajak-sajak konvensional seperti pantun, syair, gurindam, dan lain-lain adalah contoh sajak yang terikat dengan unsur formal yaitu bahasa yang tersusun dalam baris dan bait.

b. Bait

Bait dalam Kamus Besar Bahasa Indonesia merupakan satu kesatuan dalam puisi yang terdiri atas beberapa baris, seperti pantun yang terdiri dari empat baris (Moeljadi, dkk., 2016). Bait mempunyai fungsi untuk memisahkan topik-topik atau ide-ide yang diekspresikan dalam puisi. Berikut contoh bait nyanyian rakyat lullaby "Manjujai Anak".

(D5) Laloklah lalok lai nak

Lalok bajujai piciangkanlah mato nak oi

Indak elok manangih juo

'Tidurlah tidur lagi nak

Tidur berbuai pejamkan mata nak oi

Tidak baik menangis juga'

(D10) Layang-layang tabang malayang

Inggok di pagaran baniah

Baitu elok urang sumbayang

Ati e elok muko e janiah

'Layang-layang terbang melayang

Hinggap di pagaran benih 
Begitu elok orang sembahyang

Hatinya baik mukanya jernih'

Pada contoh nyanyian rakyat lullaby "Manjujai Anak" di atas (D5) adalah contoh bait yang terdiri dari tiga baris, dan (D10) memiliki empat baris dalam satu bait. Keseluruhan dari teks nyanyian rakyat lullaby Manjujai Anak terdiri dari lima belas bait. Data bait juga ditemukan beragam, ada tiga baris dan ada juga yang empat baris dalam satu bait. Selain itu jumlah kata terdapat sebelas sampai dengan dua puluh sembilan kata dalam satu bait. Sebuah bait dalam suatu puisi mengandung satu pokok pikiran (Siswanto, 2013:101). Sama halnya dengan pendapat Siswanto tersebut bait-bait dalam teks nyanyian rakyat lullaby "Manjujai Anak" memiliki satu pokok pikiran perbaitnya, seperti pada data (D10) yang memberikan maksud penggambaran diri bagi orang yang selalu taat beribadah (sembahyang).

\section{c. Diksi}

Pemilihan kata-kata yang yang dilakukan seorang penyair dalam sebuah puisi disebut diksi. Dalam teks nyanyian rakyat lullaby "Manjujai Anak" terdapat ketepatan pemakaian kata yang bersinonim anak laki-laki seperti penggunaan kata anak/nak, buyuang dan bujang. Pada teks nyanyian rakyat lullaby Manjujai Anak terlihat ketepatan dalam penempatan ketiga kata yang bersinonim tersebut. Berikut contoh teksnya.

(D1) Oi nak kanduang laloklah lalok...

'Oi nak kandung tidurlah tidur.....'

(D2) Dapek yo buyuang basarik-sarik...

...Nyo diazanan, diagiah namo si bujang sidik

'Melahirkan buyung bersusah-payah

...Dia diazankan, diberi nama si bujang Sidik'

Pemilihan kata yang tepat akan menimbulkan efek atau suasana yang baik pula terhadap puisi yang diciptakan. Hasanuddin (2002, p.101) mengungkapkan bahwa meskipun kata-kata terkadang mengandung arti yang sama, tetapi akan lebih mencekam bila penggunaan kata diperhatikan dengan kebutuhan konteks. Pada contoh teks di atas terlihat bahwa pengarang nyanyian rakyat Manjujai Anak memilih kata yang tepat dan paham dengan arti dari kata-kata yang dipergunakannya, padanan dari arti kata yang digunakannya, serta konteks sajak yang ditulisnya. Hal ini tergambar ketika sang ibu berbicara dengan anaknya (laki-laki) yang masih bayi dan balita pada (D1) terlihat bahwa sang ibu menggunakan kata 'nak' sebagai bahasa komunikasi sehari-hari. Sedangkan pada data (D2) yaitu kata 'buyuang'" digambarkan bahwa dalam teks tersebut sang ibu sedang menceritakan anak laki-lakinya yang beranjak remaja. Kemudian pada baris ke empat data (D2) pengunaan kata'bujang' juga menggambarkan anak laki-laki dari sang ibu, hanya saja dalam teks tersebut kata bujang digunakan untuk menggambarkan sang anak yang telah berumur dan sudah diberi nama atau gelar. Oleh karena itu, nyanyian rakyat lullaby Manjujai Anak ini memiliki diksi yang baik. Hal ini juga diperkuat oleh pendapat Sudjiman (dalam Hasanuddin, 2002, p.98-99) bahwa diksi yang baik berhubungan dengan pemilihan kata bermakna tepat dan selaras, yang penggunaannya cocok dengan pokok pembicaraan atau peristiwa.

\section{d. Citraan}

Ada empat citraan yang terdapat dalam teks nyanyian rakyat lullaby Manjujai Anak. Atmazaki (2008, p.119) mengungkapkan bahwa kemampuan penyair memanfaatkan saranasarana kepuitisan dengan baik akan menimbulkan kilasan bayangan dalam pembaca. Setiap kilasan itu disebut imaji atau citra, adapun citraan yang tergambar dalam teks nyanyian rakyat lullaby "Manjujai Anak" adalah sebagai berikut. 
1) Citraan Penglihatan

Adapun citraan yang ditimbulkan daya saran penglihatan dalam teks nyanyian rakyat lullaby Manjujai Anak tergambar dalam data berikut.

(D4) Ampang Kualo pacuan kudo

Rami dek anak lei tanah garam...

'Ampang Kualo pacuan kuda

Rami oleh anak lei Tanah Garam...'

Kata 'rami' pada data (D4) di atas menggambarkan sesuatu seolah-olah dapat dilihat adanya pacuan kuda yang diramaikan oleh anak-anak dari Tanah Garam. Citraan penglihatan memberi rangsangan terhadap indra penglihatan, sehingga sering hal-hal yang tidak terlihat seolah-olah terlihat.

2) Citraan Pendengaran

Adapun citraan pendengaran dalam teks nyanyian rakyat lullaby Manjujai Anak adalah sebagai berikut.

(D2) ...Dapek yo buyuang basarik-sarik

Nyo diazanan, diagiah namo si bujang sidik

'...Melahirkan buyung bersusah payah

Dia diazankan, diberi nama si bujang Sidik'

Pada teks data (D2) di atas terlihat citraan pendengaran pada kata 'Nyo diazanan'. Kata tersebut memancing indra pendengaran seolah-olah sedang mendengarkan suara adzan. Melalui kata-kata yang mengandung citraan pendengaran nyanyian rakyat lullaby "Manjujai Anak" terkesan menghadirkan suasana lebih hidup atau nyata. Hal ini sejalan dengan pendapat Hasanuddin (2002, p.120) bahwa lewat citraan pendengaran, sesuatu yang abstrak digambarkan sebagai sesuatu yang terdengar dan meransang indra pendengaran dan dapat membangkitkan suasana.

3) Citraan Rasaan

Citraan rasaan yang terdapat dalam teks nyanyian rakyat lullaby "Manjujai Anak" terlihat pada contoh data teks berikut.

(D2) ...Dapek yo buyuang basarik-sarik

Nyo diazanan, diagiah namo si bujang sidik

'...Melahirkan buyung bersusah payah

Dia diazankan, diberi nama si bujang Sidik'

Pada data teks (D2) di atas terlihat adanya citraan rasaan pada kata 'basarik-sarik' yang jika dipadankan ke dalam bahasa Indonesia berarti bersusah payah. Kata tersebut membangkitkan daya bayang pembaca seolah-olah sedang membayangkan susahnya mendapatkan seorang anak.

\section{4) Citraan Gerak} berikut.

Citraan gerak dalam teks nyanyian rakyat lullaby "Manjujai Anak" terlihat pada data

(D1) Oi nak kanduang laloklah lalok

Laloklah lalok piciangkan mato

Piciangkan mato

'Oi nak kandung tidurlah tidur 
Tidurlah tidur pejamkan mata

Pejamkan mata'

Pada data (D1) tergambar dari kata 'piciangkan mato' memancing daya bayang seolaholah disuruh untuk memejamkan mata.

5) Kata konkret

Kata konkret erat hubungannya dengan imaji. Kata konkret adalah kata-kata yang dapat ditangkap dengan indra. kata konkret dalam teks nyanyian rakyat lullaby "Manjujai Anak" dapat dilihat pada data berikut.

(D2) Dapek yo buyuang basarik-sarik

Nan jo bismillah mahanan sakik

Kini dek buyuang matoarilah tabik

Nyo diazanan, gadang banamo si bujang sidik

'Melahirkan buyung bersusah payah

Dengan bismillah menahan sakit

Kini bagi buyung matahari sudah terbit

Dia diazankan, besar bernama si bujang Sidik'

Data di atas mengandung kata konkret untuk melukiskan susahnya memperoleh keturunan dan melahirkan maka pengarang menggunakan kata-kata 'dapek yo buyuang basariksarik'. Selain itu, pada baris ke tiga data (D2) di atas juga terdapat kata-kata yang dikonkretkan yaitu pada kata 'matoarilah tabik' yang mengisyaratkan bahwa telah terbukanya kehidupan baru atau dunia baru bagi seorang anak.

\section{6) Bahasa Figuratif}

Bahasa figuratif ialah bahasa yang digunakan penyair untuk mengatakan sesuatu yang tidak biasa yang terdiri dari pengisahan yang menimbulkan makna kias. Adapun kiasan atau gaya bahasa yang terdapat dalam teks nyanyian rakyat lullaby "Manjujai Anak" adalah hiperbola yang tergambar melalui bait berikut.

(D4) Ampang Kualo pacuan kudo

Rami dek anak lei tanah garam

Oi nak kanduang sayangnyo bundo

Paubek jariah palarai damam

'Ampang Kualo pacuan kuda

Rami oleh anak lei Tanah Garam

Oi nak kandung sayangnya bunda

Pengobat jerih pelerai demam'

Hiperbola adalah kiasan yang berlebih-lebihan. Penyair merasa perlu melebih-lebihkan hal yang diungkapkannya agar mendapat perhatian yang lebih seksama dari pembaca. Sejalan dengan pendapat sudjiman (dalam Hasanuddin, 2002, p.133) bahwa bahasa yang bermajas adalah bahasa yang mempergunakan kata-kata yang yang susunan dan artinya sengaja disimpangkan dari susunan dan arti biasanya, dengan maksud mendapatkan kesegaran dan kekuatan ekspresi. Hal ini dapat dilihat pada data (D4) dengan lirik 'paubek jariah palarai damam'. Ungkapan tersebut terkesan berlebihan karena seorang anak secara logika belum tentu dapat sebagai pengobat segala penyakit. Namun, pada ungkapan tersebut mengisyaratkan bahwa seorang anak adalah obat ketika orang tua lelah dan lemah yang membuktikan bahwa ungkapan tersebut mengandung arti yang sengaja disimpangkan dengan maksud mendapat perhatian lebih pendengar dan memiliki kekuatan tersendiri dari lirik tersebut. 
7) Rima

Rima adalah pengulangan bunyi dalam puisi untuk membentuk musikalitas atau oskestrasi. Dengan adanya pengulangan bunyi tersebut, puisi menjadi merdu jika dibaca. Pada teks nyanyian rakyat lullaby "Manjujai Anak" ini terdapat rima berpola aa-aa dan ab-ab. tergambar dalam contoh teks nyanyian Manjujai Anak berikut.

(D2) Dapek yo buyuang basarik-sarik

Nan jo bismillah mahanan sakik

[aa-aa]

Nyo diazanan, gadang banamo si bujang sidik

Melahirkan buyung bersusah payah

Dengan bismillah menahan sakit

Kini bagi buyung matahari sudah terbit

Dia diazankan, besar bernama si bujang Sidik'

(D4) Ampang Kualo pacuan kudo

Rami dek anak lei tanah garam [ab-ab]

Oi nak kanduang sayangnyo bundo

Paubek jariah palarai damam

'Ampang Kualo pacuan kuda

Rami oleh anak ya Tanah Garam

Oi nak kandung sayangnya bunda

Pengobat jerih pelerai demam'

Pada contoh teks nyanyian rakyat lullaby "Manjujai Anak" di atas terlihat bahwa (D2) merupakan contoh teks nyanyian rakyat lullaby yang memiliki rima yang berpola aa-aa. Sedangkan pada data (D4) terlihat rima yang berpola ab-ab. berdasarkan hasil identifikasi dan klasifikasi data yang telah penulis lakukan keseluruhan data nyanyian rakyat lullaby "Manjujai Anak" memiliki rima berpola aa-aa terdapat dua bait dan rima yang memiliki pola ab-ab terdapat lima bait.

Rima tidak hanya berfokus pada kesamaan bunyi. Hal ini sejalan dengan pendapat Waluyo (1987, p.90) bahwa rima menyangkut perpaduan bunyi konsonan dan vokal untuk membangun oskestrasi atau musikalitas. Adapun bunyi yang dapat memberikan warna suasana tertentu seperti yang diharapkan penyair adalah kakafoni dan efoni. Pada teks nyanyian rakyat lullaby "Manjujai Anak" terdapat kakafoni dan efoni. Kakafoni adalah bunyi yang dapat menimbulkan efek keburaman dalam sajak, berikut contoh data teks kakafoni dalam nyanyian rakyat lullaby "Manjujai Anak" masyarakat Kampuang Tabek Jorong Koto Tingga Nagari Sirukam Kecamatan Payung Sekaki Kaupaten Solok.

(D12) Oi nak kanduang rambahlah paku

Buliah nak tarang jalan ka parak

Yo nak kanduang eloklah laku

Buliah nak sayang rang bakeh awak nak

'Oi nak kandung rambahlah paku

Boleh hendak terang jalan ke parak

Ya nak kandung eloklah laku

Boleh hendak sayang orang ke kita

Teks bait (D12) di atas terlihat dominannya penggunaan bunyi konsonan /k/ yang memberikan efek keburaman dan menciptakan perasaan jiwa tertekan, gelisah, bahkan memuakan. Dalam nyanyian rakyat lullaby "Manjujai Anak" ini juga terdapat bunyi efoni, di mana bunyi ini dapat menimbulkan efek cerah yang dapat menimbulkan rasa kantuk bagi si 
anak/bayi. Berikut adalah data teks nyanyian rakyat lullaby "Manjujai Anak" yang terdapat efoni.

(D1) Oi nak kanduang laloklah lalok

Laloklah lalok piciangkan mato

Piciangkan mato

'Oi nak kandung tidurlah tidur

Tidurlah tidur pejamkan mata

Pejamkan mata'

Contoh teks di atas dikatakan sebagai efoni disebabkan terdapat kesan dengan suasana cerah yang mampu membangkitkan semangat, rasa riang, serta nyaman. Pada teks (D1) bait tersebut konsonan /// terkesan menimbulkan sugesti pada gerakan yang mengalir pelan-pelan, melambai-lambai, menggairahkan, dan damai. Selain bunyi kakafoni dan efoni dalam teks nyanyian rakyat lullaby Manjujai Anak juga terdapat bunyi aliterasi dan asonansi. Pengulangan bunyi dalam satu rangkai kata-kata yang berdekatan (dalam satu baris) berupa bunyi konsonan disebut aliterasi, sedangkan persamaan bunyi vokal disebut asonansi. Pada teks nyanyian rakyat lullaby "Manjujai Anak" terdapat kedua hal tersebut yang muncul secara terpola dan dominan. Berikut data teks nyanyiannya.

(D5) Laloklah lalok lai nak...

'Tidurlah tidur lagi nak...'

Data pada (D5) terdapat aliterasi yaitu pengulangan bunyi konsonan /1/. Perulangan bunyi tersebut berlaku diantara kata-kata dalam satu larik dan disebut juga sebagai rima dalam. Menurut Aminuddin (2009, p.138) rima dalam adalah yang berlaku diantara kata-kata dalam satu larik. Kemudian asonansi dalam teks nyanyian rakyat lullaby "Manjujai Anak" terdapat pada data-data berikut.

(D13) ...Laloklah lalok piciangkan mato...

'...Tidurlah tidur pejamkan mata...'

(D14) ...kalau durako hiduik binaso

'...Kalau durhaka hidupkan binasa'

Kedua data di atas disebut asonansi disebabkan adanya perulangan bunyi vokal /o/ yang dominan seperti pada laloklah lalok piciangkan mato dan kalau durako, hiduikan binaso. Selain itu, pada teks nyanyian rakyat lullaby "Manjujai Anak" juga terdapat rima yang identik. Hal ini terdapat pada kata 'lalok' yang dapat dijumpai pengulangannya diantara bait-bait. Bentuk rima terakhir dalam teks nyanyian rakyat ini adalah adanya pengulangan kata/frasa/ungkapan. Hal ini dapat dilihat pada bait berikut.

(D1) Oi nak kanduang laloklah lalok

Laloklah lalok piciangkan mato

Piciangkan mato

'Oi nak kandung tidurlah tidur

Tidurlah tidur pejamkan mata

Pejamkan mata'

(D7) Laloklah lalok nak

Lalok bajujai piciangkanlah mato nak oi

Indak elok manangih juo

'Tidurlah tidur nak

Tidur berbuai pejamkanlah mata nak oi 
Tidak baik menangis juga'

Data pada (D1) di atas terdapat pengulangan frasa pada akhir larik seperti piciangkanlah mato. Pengulangan ini biasanya disebut dengan katafora. Sedangkan pada (D7) yaitu pada kata lalok terjadi pengulangan kata pada awal larik dan biasanya disebut dengan anafora.

\section{Struktur Batin}

Makna yang terkandung di dalam puisi yang tidak secara langsung dapat dihayati disebut dengan struktur batin puisi. I. A. Richards berpendapat bahwa struktur batin puisi terdiri atas empat unsur yaitu tema atau makna, rasa, nada, amanat atau tujuan. Struktur batin teks nyanyian rakyat lullaby Manjujai Anak akan dianalisis berdasarkan struktur batin menurut I.A Richards (dalam Waluyo, 1987, p.102), sebagai berikut.

a. Tema atau makna

Tema yang diangkat oleh pelantun nyanyian rakyat lullaby "Manjujai Anak" adalah tema adat dan agama. Tema dalam penelitian ini dapat dilihat melalui bait-bait dalam teks nyanyian rakyat tersebut. Adapun tema adat dan agama tergambar melalui bait berikut.

(D6) Sawah Solok di tapi jalan

Hiliran banda nagari Salayo

Oi nak kanduang sayang di badan

Tahu dia diadaik jo agamo

'Sawah Solok di tepi jalan

Hiliran bandar nagari Salayo

Oi nak kandung sayang dengan badan

Tahu dengan adat dan agama'

Bait (D6) di atas mengangkat tema adat dan agama tergambar dari lirik ketiga dan empat pada bait tersebut. Seorang ibu digambarkan mendidik anaknya untuk mengetahui adat dan agama dalam artian menjalani hidup dengan berpedoman kepada adat dan agama. Hal ini tidak lain disebabkan untuk tetap menjaga harkat dan martabatnya sebagai seorang manusia yang memiliki kepribadian yang baik. Selain itu, di dalam teks nyanyian rakyat lullaby Manjujai Anak ini juga tergambar tema agama saja. Hal ini dapat dilihat melalui bait berikut.

(D8) Simpang Tabek nagari Sirukan

Di sinan bundo manggaleh singgang

Nak sayang bundo balahan badan

Capeklah gadang rajin sumbayang

'Simpang Tabek nagari Sirukam

Di situ bunda menjual singgang

Nak sayang bunda belahan badan

Cepatlah besar rajin sembahyang

Data teks nyanyian rakyat lullaby "Manjujai Anak" di atas bertemakan agama. Hal ini dapat dilihat pada baris ketiga dan keempat dari bait di atas yang menggambarkan desakan yang kuat berupa pendidikan yang diajarkan pelantun untuk anaknya terkait hubungannya dengan Tuhan seperti rajin sembahyang.

b. Rasa

Rasa dalam puisi adalah sikap penyair terhadap pokok permasalahan yang terdapat dalam puisi. Dalam menciptakan sebuah puisi suasana perasaan penyair ikut diekspresikan. Perasaan 
yang digambarkan pelantun dalam teks nyanyian rakyat lullaby "Manjujai Anak" tergambar melalui data berikut.

(D2) ..Dapek yo buyuang basarik-sarik

Nyo diazanan, diagiah namo si bujang sidik

'...Dapat ya buyung bersusah payah

Dia diazankan, diberi nama si bujang Sidik'

Data di atas menggambarkan rasa senang pelantun nyanyian tersebut terhadap kehadiran seorang anak dalam kehidupannya. Hal ini ditandai dengan kata-kata "Nyo diazanan, diagiah namo si bujang sidik' mengazankan dan memberi nama adalah sebagai bentuk rasa senang orang tua dalam nyanyian tersebut. selain rasa senang juga terdapat rasa cinta kasih yang tergambar dalam bait berikut.

(D4) ...Oi nak kanduang sayangnyo bundo

Paubek jariah, palarai damam

'...Oi nak kandung sayangnya bunda

Pengobat jerih pelerai demam’

Data di atas adalah gambaran dari perasaan cinta kasih dari orang tua kepada anaknya yang mana anaknya digambarkan sebagai obat jerih dan penyakitnya. Adapun nada yang dapat ditangkap pendengar dalam teks nyanyian rakyat lullaby "Manjujai Anak" tergambar melalui data berikut.

(D1) Oi nak kanduang laloklah lalok

Laloklah lalok piciangkan mato

Piciangkan mato

'Oi nak kandung tidurlah tidur

Tidurlah tidur pejamkan mata

Pejamkan mata'

Pada (D1) di atas terlihat pelantun nyanyian rakyat lullaby "Manjujai Anak" bernada memerintah untuk menyampaikan tema dan rasa yang dimaksudnya sehingga sang anak terasa diperintah untuk mengitu apa yang diinginkan pelantun. Selain itu juga terdapat nada lain yang diterima oleh pendengar dalam teks nyanyian rakyat ini seperti dalam data berikut.

(D14) Nak kanduang lalok dijujai bundo

Lalok bajujai badendang pulo, badendang pulo

Gadanglah lai nak pi jan durako

Kalau durako hiduikan binaso, hiduikan binaso

'Nak kandung lalok dibuai bunda

Tidur berbuai berdendang pula, berdendang pula

Besarlah lagi nak tetapi jangan durhaka

Kalau durhaka hidupkan binasa, hidupkan binasa'

Data di atas tergambar perasaan pendengar dengan nada haru. Hal ini tergambar pada baris ke tiga dan ke empat pada masing-masing data di atas. Pelantun terkesan sedang menggurui pendengarnya sehingga pendengarnya merasa terharu akan nasehat yang diberikan ketika melantunkan lirik nyanyian rakyat lullaby "Manjujai Anak". 
c. Amanat

Amanat merupakan hal yang mendorong penyair untuk menciptakan puisinya. Amanat tersirat di balik kata-kata yang disusun, dan juga berada di balik tema yang diungkapkan. Amanat yang terdapat dalam teks nyanyian rakyat lullaby "Manjujai Anak" adalah senantiasalah bersyukur atas pemberian Allah dalam kehidupan kita. Hal ini dapat dilihat melalui data berikut.

(D1) Oi nak kanduang laloklah lalok

Laloklah lalok piciangkan mato

Piciangkan mato

'Oi nak kandung tidurlah tidur

Tidurlah tidur pejamkan mata

Pejamkan mata'

Data di atas mengandung amanat untuk menyuruh anak segera tertidur supaya kesehatan anak terjaga. Anak-anak usia dini terutama bayi dianjurkan untuk tidur lebih banyak seperti tidur siang karena penting bagi tumbuh kembang anak dan dapat memberikan banyak dampak positif jika dilakukan teratur salah satunya dapat meningkatkan kemampuan kognitif anak.

\section{Fungsi Sosial Nyanyian Rakyat Lullaby Manjujai Anak Masyarakat Kampuang Tabek Jorong Koto Tingga Nagari Sirukam Kecamatan Payung Sekaki Kabupaten Solok}

Setiap nyanyian rakyat memiliki fungsi tersendiri bagi masyarakat pemilik tradisi lisan tersebut. fungsi sosial dalam nyanyian rakyat adalah kegunaan nyanyian rakyat tersebut di tengah-tengah masyarakat. Nyanyian rakyat lullaby "Manjujai Anak" masyarakat Kampuang Tabek Jorong Koto Tingga Nagari Sirukam Kecamatan Payung Sekaki Kabupaten Solok ini memiliki beberapa fungsi sosial di antaranya sebagai berikut.

\section{Sebagai Sistem Proyeksi}

Nyanyian rakyat lullaby Manjujai Anak sebagai sistem proyeksi yakni menggambarkan angan-angan dan harapan orang tua masyarakat Kampuang Tabek Jorong Koto Tingga Nagari Sirukam Kecamatan Payung Sekaki Kabupaten Solok. Hal ini terlihat pada data dalam lirik nyanyian berikut.

(D8) Simpang Tabek Nagari Sirukan

Di sinan bundo manggaleh singgang

Nak sayang bundo balahan badan

Capeklah gadang rajin sumbayang

'Simpang Tabek Nagari Sirukam

Di situ bunda menjual singgang

Nak sayang bunda belahan badan

Cepatlah besar rajin sembahyang

Data lirik di atas mengisyaratkan harapan pelantun terhadap anaknya agar dewasa kelak anaknya rajin beribadah (sembahyang). Silaban (2015) dalam penelitiannya tentang tradisi lisan nyanyian rakyat anak pada masyarakat Batak Toba yang hasil penelitiannya juga berkesimpulan bahwa nyanyian rakyat Dideng (pengantar tidur anak) sebagai media untuk menyampaikan doa dan harapan untuk anak. Selain sejalan dengan penelitian Silaban (2015), nyanyian Manjujai Anak ini sebagai sistem proyeksi juga diperkuat oleh informasi dari informan Hamna Riza (41) berjenis kelamin perempuan yang mengatakan bahwa nyanyian rakyat ini mampu 
menggambarkan harapan atau keinginan kita kepada sang anak suatu saat nanti seperti berperilaku yang baik. Harapan yang disampaikan orang tua lewat jujaian berisi tentang pesanpesan yang mengandung nilai moral.

\section{Sebagai Alat Pendidikan Anak}

Nyanyian rakyat lullaby "Manjujai Anak" diperuntukkan bagi bayi dan anak-anak usia dini. Proses belajar mereka berbeda dengan anak-anak pada umumnya yang bisa belajar melalui sekolah dan pengaruh lingungan sekitar, sedangkan bayi dan anak-anak usia dini hanya banyak menghabiskan waktu dan bisa belajar melalui orang tuanya. Oleh sebab itu nyanyian ini berfungsi sebagai alat pendidikan bagi anak oleh masyarakat Kampuang Tabek Jorong Koto Tingga Nagari Sirukam. Selain itu dalam teks nyanyian rakyat lullaby "Manjujai Anak" juga terdapat larik-larik yang berfungsi mendidik dengan berbagai pelajaran yang mengandung nilainilai kemanusiaan dan ketuhanan. Hal ini dapat dilihat melalui data teks berikut.

(D6) Sawah Solok di tapi jalan

Hiliran banda nagari Salayo

Oi nak kanduang sayang di badan

Tahu diadaik jo agamo

'Sawah Solok di tepi jalan

Hiliran bandar nagari Salayo

Oi nak kandung sayang dengan badan

Tahu dengan adat dan agama'

Data di atas menjelaskan bahwa dalam teks nyanyian rakyat lullaby "Manjujai Anak" terdapat kata-kata yang mendidik seperti yang terlihat pada baris ketiga dan ke empat dalam data teks di atas. Selain itu, menurut informasi dari informan Hamna Riza (41) berjenis kelamin perempuan melalui nyanyian rakyat lullaby Manjujai Anak terdapat pesan-pesan moral, petuah, dan pengajaran yang diberikan oleh orang tua sehingga secara tidak langsung anak akan mulai belajar. Hal ini karena menurutnya seorang anak harus diberikan didikan mulai dari ia kecil. Kemudian ia percaya bahwa nasihat yang disampaikannya lewat jujaian dapat dimengerti oleh sang anak yang mendengarkannya. Oleh karena itu, nyanyian rakyat lullaby Manjujai Anak memiliki fungsi sebagai alat pendidikan anak.

\section{Rekreatif}

Nyanyian rakyat lullaby "Manjujai Anak" berfungsi sebagai rekreatif, meskipun sementara waktu. Tidak dapat dipungkiri bahwa fungsi yang paling menonjol dari sebuah sastra lisan adalah untuk menghibur. Oleh karena itu, nyanyian rakyat lullaby ini juga mampu sebagai alat untuk merenggut diri dari kebosanan hidup sementara waktu ataupun untuk pelipur lara. Hal ini dapat dilihat melalui data teks berikut.

(D8) Simpang Tabek nagari Sirukan

Di sinan bundo manggaleh singgang

Nak sayang bundo balahan badan

Capeklah gadang rajin sumbayang

'Simpang Tabek nagari Sirukam

Di situ bunda menjual singgang

Nak sayang bunda belahan badan

Cepatlah besar rajin sembahyang

Data di atas menjelaskan bahwa melalui teks nyanyian rakyat sang pelantun kreatif dalam menggunakan kata-kata untuk menyampaikan bahwa sebenarnya sang pelantun seorang yang 
berprofesi sebagai pedagang. Untuk melepas penatnya sementara waktu atau untuk memulai perkerjaanya ia bernyanyi dulu sebagai bentuk hiburan baginya. Hal ini juga diperkuat oleh penelitian yang dilakukan oleh Al-Afandi tentang fungsi dan nilai nyanyian Buaian dalam sastra lisan Kaili. Dari penelitian tersebut terlihat juga bahwa nyanyian Buaian dalam sastra lisan Kaili memiliki fungsi hiburan yang menggunakan karya satra untuk menghibur anak dalam buaian terlihat dari lirik yang memberi nuansa yang bersajak dan susunan kata yang memiliki kekuatan stilistika atau gaya bahasa yang digunakan penyair. Selain itu, berdasarkan informasi dari informan Hamna Riza (41) berjenis kelamin perempuan mengatakan bahwa nyanyian rakyat ini dapat dijadikan perintang hati dan pelipur lara. Informan sendiri mengakui bahwa dalam menyanyikan lagu Manjujai Anak ini ia terkadang-kadang mengisi liriknya sambil bercerita tentang permasalahan hidup yang dijalaninya sebagai bentuk memberikan nasehat kepada anaknya. Oleh karena itu, nyanyian rakyat lullaby "Manjujai Anak" ini berfungsi sebagai rekreatif bagi masyarakat pemiliknya.

\section{Pewarisan Tradisi Lisan}

Nyanyian rakyat lullaby "Manjujai Anak" sebagai pewarisan tradisi lisan bagi masyarakat pemilik nyanyian tersebut. Sastra lisan yang berfungsi sebagai pewarisan tradisi adalah alat untuk meneruskan tradisi suatu bangsa dalam arti positif (Semi, 1988, p.20). Nyanyian rakyat ini diwariskan secara turun-temurun melalui tutur kata atau ujaran. Bagi masyarakat Kampuang Tabek nyanyian rakyat ini diwariskan guna mengetahui bahwa dahulunya nenek moyang mereka menidurkan anaknya dengan cara manjujai sang anak. Selain itu, ketika manjujai anak juga bisa diberikan nasehat dalam menjalani hidup sehari-hari. Hal ini dapat dibuktikan dalam kutipan berikut.

(D14) Nak kanduang lalok dijujai bundo

Lalok bajujai badendang pulo

Gadanglah lai nak pi jan durako

Kalau durako hiduikan binaso

'Nak kandung lalok dibuai bunda

Tidur berbuai berdendang pula

Besarlah lagi nak tetapi jangan durhaka

Kalau durhaka hidupkan binasa'

Kutipan di atas menjelaskan bahwa nyanyian rakyat lullaby "Manjujai Anak" ini berfungsi sebagai pewarisan tradisi lisan. Adapun warisan yang dimaksud di sini adalah mempertahankan suatu nilai positif yaitu dilarang untuk durhaka. Selain itu, berdasarkan informasi dari informan yang bernama Hamna Riza (41) berjenis kelamin perempuan ketika diwawancarai pada tanggal 2 Februari 2020 mengatakan bahwa tradisi lisan tersebut didapatkannya dari mendengarkan neneknya manjujai cucu beliau. Oleh sebab itu, nyanyian rakyat lullaby "Manjujai Anak" ini memiliki fungsi pewarisan tradisi lisan.

\section{Simpulan}

Berdasarkan hasil penelitian Struktur dan Fungsi Sosial Nyanyian Rakyat Lullaby "Manjujai Anak" Masyarakat Kampuang Tabek Jorong Koto Tingga Nagari Sirukam Kecamatan Payung Sekaki Kabupaten Solok, temuan yang diperoleh dapat disimpulkan bahwa struktur dalam penelitian ini terdapat dua, yaitu struktur fisik dan struktur batin. Struktur fisik terdiri dari perwajahan puisi, diksi, citraan, kata konkret, bahasa figuratif, dan verifikasi, sedangkan struktur batin ada empat yaitu tema atau makna, rasa, nada, dan amanat. Kedua struktur ini secara padu saling mengikat dan membentuk totalitas makna yang utuh. Melalui struktur ini terlihat bahwa di dalam teks nyanyian rakyat lullaby "Manjujai Anak" ini terdapat puisi lama seperti pantun dan syair yang membuktikan bahwa nyanyian rakyat ini masih terikat dalam jumlah kata dalam setiap baris dan jumlah baris dalam setiap bait, 
Nyanyian rakyat lullaby "Manjujai Anak" oleh masyarakat Kampuang Tabek Jorong Koto Tingga Nagari Sirukam Kecamatan Payung Sekaki Kabupaten Solok memiliki empat fungsi sosial yaitu sebagai sistem proyeksi, sebagai alat pendidikan anak, sebagai rekreatif, dan pewarisan tradisi lisan. Jadi, melalui analisis terhadap struktur dan fungsi sosial nyanyian rakyat lullaby Manjujai Anak ini dapat diketahui tentang falsafah, persepsi, dan perilaku sosial masyarakat, salah satunya seperti masyarakat Kampuang Tabek yang gemar berpantun.

\section{Referensi}

Al-Afandi. (2015). "Fungsi dan nilai nyanyian buaian dalam sastra lisan Kaili”. Tesis Magister. Palu: Universitas Tadaluko.

Aminuddin. (2009). Pengantar apresiasi puisi karya sastra. Bandung: Sinar Baru.

Atmazaki. (2008). Analisis sajak: Teori, metodologi \& aplikasi. Padang: UNP Press.

Danandjaja, J. (1991). Folklor Indonesia (ilmu gosip, dongeng, dan lain-lain). Jakarta: Pustaka Utama Grafiti.

Desmita. (2006). Psikologi perkembangan. Bandung: PT Remaja Rosdakarya.

Fitriana, R. (2019). "Nilai-nilai tunjuk ajar Melayu di dalam teks nandong di kecamatan pangean kabupaten Kuantan Singingi”. Tesis Magister. Padang: Universitas Negeri Padang.

Hasanuddin WS, dkk. (2020). Text of Oral tradition Of Lullaby Songs Mainland Region of the Minangkabau Collective: Format, Content, and Functions in Proceeding Internasional Conference Language, Literature and education (ICLLE 2020) on Agust 12-13, Padang. Indonesia, Advanced in Sosial Science, Education and Humanities Research, Volume 485, ISBN Publising.

Hasanuddin WS. (2002). Membaca dan menilai sajak: Penggantar pengkajian dan interpretasi. Bandung: Angkasa Bandung.

Https://Langgam.id/nagari-sirukam-payung-sekaki-kabupaten-solok.

Marantes, dkk. (2018). "Pemaknaan terhadap dendang mengasuh anak (Kajian Semantik)". Jurnal Elektronik Wacana Etnik 7(1):11-18.

Moeljadi, dkk. (2016). Kamus Besar Bahasa Indonesia Edisi V.

Ratna, N. K. (2011). Teori, metode, dan teknik penelitian sastra dari strukturalisme hingga postrukturalisme perspektif wacana naratif. Yogyakarta: Pustaka Pelajar.

Salahuddin, A. (2014). Tradisi lisan maoundu pojo: Senandung menidurkan anak masyarakat kabupaten Lima Puluh Kota Sumatera Barat. Padang: Suka Bina Press.

Semi, M. A. (1984). Anatomi Sastra. Padang: Sridharma.

Silaban, D. M. P. (2015). "Tradisi lisan nyanyian rakyat anak-anak pada masyarakat Batak Toba di Kecamatan Lintongnihuta kabupaten Humbang Hasundutan”. Tesis Magister. Medan: Program Studi Linguistik FIB USU.

Siswanto, W. (2008). Pengantar teori sastra. Jakarta: Grasindo.

Syamsuddin, dan Vismaia S. D. (2011). Metode penelitian pendidikan bahasa. Bandung: PT Remaja Rosda Karya.

Waluyo, H. J. (1987). Teori dan apresiasi puisi. Jakarta: Erlangga. 